\title{
EDUCATIONAL CHALLENGES FACING SWEDISH PHYSICAL EDUCATION TEACHING IN THE 2020s
}

\author{
DESAFIOS EDUCACIONAIS PARA O ENSINO DA EDUCAÇÃO \\ FÍSICA SUECA NA DÉCADA DE 2020
}

DESAFÍOS EDUCATIVOS PARA LA EDUCACIÓN FÍSICA SUECA EN 2020

\author{
Karin Redelius*, Håkan Larsson *
}

\section{Keywords:} Physical

Education.

Teaching.

Assessment. Neoliberalism.

Palavras chave: Educação Física. Ensino.

Avaliação. Neoliberalismo.

Palabras clave: Educación Física. Enseñanza.

Evaluación. Neoliberalismo.

\begin{abstract}
Many countries around the world have experienced neoliberal turns which strongly affected educational systems. In Sweden, for example, the social democratic Welfare State has taken a radical neoliberal turn since the 1990s. A number of school reforms have been carried out and they are described as the most extensive in a hundred years of public schooling. These changes have also affected the subject of Physical Education and Health (PEH). Growing research interest is one of those changes, and PEH has become one of the most explored areas in Swedish physical culture. This article points to some of the new research, identifying and formulating possible educational challenges facing teachers as we move into the 2020s. Central questions are: What characterizes teaching in PEH? What do students learn in the subject? Is there effective evaluation in Swedish $\mathrm{PEH}$ ?
\end{abstract}

Resumo: Muitos países pelo mundo vivenciaram uma virada neoliberal que fortemente afetou seus sistemas educacionais. Na Suécia, por exemplo, o Estado de Bem-Estar social-democrata foi radicalmente transformado desde a década de 1990, tomando uma direção neoliberal. Numerosas reformas educacionais foram realizadas, sendo estas descritas como as mais extensas em 100 anos do ensino público. Essas mudanças também afetaram a disciplina Educação Física e Saúde (PEH). Há um crescente interesse acerca desse tema e a PEH se tornou uma das áreas mais exploradas da cultura de movimento sueca. Os objetivos deste artigo são indicar as pesquisas recentes, bem como identificar e formular possíveis mudanças educacionais que professores enfrentam hoje enquanto caminhamos em direção à década de 2020. As questões centrais são: o que caracteriza o ensino em $\mathrm{PEH}$ ? O que os estudantes aprendem nessa matéria? Existe eficácia na avaliação da PEH sueca?

Resumen: Muchos países alrededor de mundo han experimentado un cambio neoliberal que ha afectado fuertemente sus sistemas educativos. En Suecia, por ejemplo, el Estado de Bienestar Socialdemócrata se ha transformado radicalmente, desde los años 90 , en una dirección neoliberal. Se han llevado a cabo numerosas reformas escolares, descritas como las más extensas en 100 años de educación pública. Estos cambios también afectaron a la Educación Física y Salud (PEH). Hay un creciente interés en este tema y la PEH se ha convertido en una de las áreas más exploradas de la cultura de movimiento sueca. Los propósitos de este artículo son señalar investigaciones recientes, identificar y formular posibles cambios educativos que actualmente enfrentan los maestros, a medida que avanzamos hacia la década de 2020. Las preguntas centrales son: ¿qué caracteriza la enseñanza en PEH? ¿Qué aprenden los estudiantes en esta materia? ¿Hay efectividad en la evaluación de la PEH sueca?
*The Swedish School of Sport and Health Sciences $(\mathrm{GIH})$. Estocolmo, Suécia.

E-mail:

karin.redelius@gih.se; hakan.larsson@gih.se

Received on: 09-12-2019 Approved on: 20-03-2020 Posted on: 21-03-2020

(c) (i) (2) Licence 


\section{INTRODUCTION}

Many countries around the world have experienced a neoliberal turn, which has powerfully affected their educational systems (CONNELL, 2013). In Sweden, for example, the social democratic welfare state has been radically transformed in a neoliberal direction, especially in the last three decades. A number of school reforms have been carried out - which have been described as the most extensive in a hundred years of public schooling (NILSSON LINDSTRÖM; BEACH, 2015). The entire system has gone from being one of the most centralised in the western world to one of the least centralised (DAUN, 2004). In the past, the government dictated how the work of schools should be organised and implemented, and especially what the subject matter of the various subjects ought to be. Nowadays, the government dictates the school result by stipulating which goals or learning outcomes students should achieve and which abilities they should develop. The system has thus been transformed from a rule-driven operation to a goal-driven one. Accordingly, school reforms have also meant a shift in the educational focus - from what schools should teach to what students should learn. As Carlgren and Marton (2000, p. 92) point out, teachers' work has thereby changed from

[...] focusing on teaching to focusing on learning, from thinking about methods to thinking about goals and outcomes, from being occupied with what the teacher does to what the student perceives (our translation).

According to this perspective, a greater emphasis should now be placed on what students actually learn and their level of knowledge in relation to the stated goals. Judgements about the distribution of grades are to be made against specified criteria, or 'knowledge requirements', as they are now called. The pedagogical responsibility for facilitating the achievement of these goals is devolved to the teachers. In this way, great confidence is expressed in how teachers teach and what they teach as long as the students achieve the stated learning outcomes. As teachers are solely responsible for awarding grades, they therefore play an important role in the assessment and grading process.

The change from a rule-driven to a goal- and result driven school system have also affected the subject of physical education (PE). The name, for example, has changed from $P E$ to physical education and health $(\mathrm{PEH})$, which means that a more pronounced health perspective is now present in the national syllabus for the subject. A greater research interest in $\mathrm{PEH}$ has also emerged in the wake of these reforms. Before the year 2000, very few researchers in Sweden were interested in issues related to PE. The pedagogue Claes Annerstedt, whose main interest concerns didactics in PE, was one of the pioneers in this field (ANNERSTEDT, 1991). Since the year 2000, however, PEH has become one of the most explored areas of Swedish physical culture. Around ten years ago, this awakened research interest, alongside the educational reforms that had been carried out, prompted us to review the state of Swedish PE teaching and research and, on that basis, formulate a number of educational challenges for PE teaching (REDELIUS; LARSSON, 2010). One of the most prominent challenges we identified was how to transform PEH from a practical subject for "fun and recreation" to a subject for learning. Relevant questions to ask 
today are whether PEH has become a subject for learning and what the current challenges for teaching are as we approach a new decade.

Researchers still have an immense interest in $\mathrm{PEH}$ and a number of $\mathrm{PhD}$ theses, journal articles, reports and government evaluations have been produced during the last ten years. What is more, yet another curriculum with new syllabuses and knowledge requirements for all subjects has been implemented in Swedish schools (SKOLVERKET; 2011; updated version 2020). The aim of this article is to point to some of the new research and to identify possible educational challenges that teachers face in Swedish PEH today as we have just moved into the 2020s. Central questions are: What characterises the teaching in $\mathrm{PEH}$ ? What do students learn in the subject? Is there assessment efficacy in Swedish $\mathrm{PEH}$ ?

\section{SWEDISH PHYSICAL EDUCATION AND HEALTH}

Before trying to answer the above questions, we will offer a short overview of the conditions framing the subject in the Swedish primary and secondary schools. $\mathrm{PEH}$ is a mandatory subject for Swedish students. Given that co-education has been stipulated in the syllabus since the 1980s, girls and boys have PEH together and that is how most of the teaching is carried out. As already mentioned, the system is goaldriven and there should be a constructive alignment between what is described in the syllabus as general aims, main content and knowledge requirements (the same as grading criteria/learning outcomes). Some of the general aims for teaching in the subject of PEH are as follows (SKOLVERKET, 2020). Teaching in PEH should aim at students developing all-round movement capacity and an interest in being physically active and spending time outdoors in nature. Through the teaching, students should encounter different kinds of activities. Students should be given the opportunity to develop knowledge about which factors affect their physical capacity and how they can safeguard their health throughout their lives. Students should also be given opportunities to develop healthy lifestyles and knowledge about how physical activity relates to mental and physical well-being. Through the teaching, students should develop the ability to spend time in outdoor settings and nature throughout the year and acquire an understanding of the value of an active outdoor life. The teaching should also contribute to students developing knowledge about the risks and safety factors related to physical activities and how to respond to emergency situations.

According to the national curriculum, teaching in PEH should essentially give students opportunities to develop four specific - yet also overall - abilities: 1) to move without restriction in different physical contexts; 2) to plan, implement and evaluate sports and other physical activities based on different views of health and, 3 ) to carry out and adapt their recreational and outdoor life to different conditions and environments; and 4) to promote safety and prevent risks during physical activities and to manage emergency situations on land and in water (SKOLVERKET, updated version 2020). 


\section{RESEARCH ON TEACHING AND LEARNING IN SWEDISH PEH}

Above we outlined the official goals of PEH in Swedish nine-year compulsory schools. In this section, the overarching question is: What does teaching in $\mathrm{PEH}$ look like in Swedish schools and what do students learn in the subject - according to the existing scholarly research on the topic? The contemporary Swedish research is quite extensive and it is not our ambition to summarise it here; rather, we would like to point to two main topics that have been given special attention. These topics concern teaching and learning, and assessment and grading respectively. They affect both overall pedagogical issues highlighted in the general national curriculum, as well as subject-specific issues highlighted in the national syllabus for $\mathrm{PEH}$. The educational issues relate mainly to prevailing social norms and conditions regarding, for example, gender, the body and what is valued in terms of student behaviour. The subject specific issues are predominantly about which knowledge is valued in the subject, especially movement capability (a concept that is used in deliberate contrast to notions such as 'skill' and 'motor ability') and the PEH practice.

It should be noted, that although the research is inevitably affected by the national context, for example regarding policy documents and cultural traditions of PEH (mainly dance and outdoor activities, so called friluftsliv), the Swedish research relates closely to international research on physical education. This was evident as Swedish researchers, over the course of a decade after the turn of the millennium, almost completely changed from publishing in Swedish to publishing in international (English-speaking) journals. Concerning theoretical anchoring, the Swedish $\mathrm{PEH}$ research balance between a European continental tradition of didactics, and an AngloAmerican tradition of curriculum studies. Finally, although most of the Swedish PEH research relates to international research on similar topics, some significant themes are missing, for example racism, and talent identification and development. Arguably, a reason for this may be that racism has not been as prominent in the public debate as gender, and talent identification is a matter for Swedish sport clubs and not for Swedish schools.

\subsection{EDUCATION, THE BODY AND GENDER}

As was stated above, the 1994 school reform meant significant changes regarding the aims and scope of $\mathrm{PEH}$. To put it simple, the shift can be framed as a transition from recreational purposes and a focus on physical, mental and social training towards educational purposes. This transition also mirrors a more general trend in school governance at a national level: that is, to focus on learning outcomes in all school subjects. Hence, central questions among $\mathrm{PEH}$ researchers have been to study what this shift in the national curriculum has meant to PEH practice. For some time a simple way of answering these questions have been "not much". The transition from training to education led to a number of challenges for $\mathrm{PEH}$ teachers and $\mathrm{PEH}$ teacher educators that were difficult to address. In 2004, a number of researchers contributed insights into the PEH practice in an edited research report entitled Mellan nytta och nöje (in English, "Between utility and pleasure"; LARSSON; REDELIUS, 2004; for an English synthesis of this research see LARSSON; REDELIUS, 2008; 
REDELIUS; LARSSON, 2010). The title highlights a tension between what PEH teachers value about the subject and what is actually going on in practice. In summary, the tension revolved around two different conceptualisations of the subject as either being "physical activity for health" (utility) or "physical activity for pleasure". Physical activity for health centred on the health-related benefits of physical activity "there and then", whereas physical activity for pleasure centred on providing students with pleasurable experiences due to being physically active, so that they would be more likely to choose a physically active lifestyle in the future.

Another important theme in the above edited research report was the tension between physical activity per se, e.g. for the purpose of overcoming sedentariness and obesity, and physical activity - or movement - for educational purposes. This tension is even more pronounced in Jan-Eric Ekberg's thesis (title in English "Between physical education and activation"; EKBERG, 2009, 2016), which reveals that although the curriculum documents highlight education in terms of exploration, creativity and the production of knowledge, the PEH practice largely focuses on reproducing predetermined knowledge about established movement activities, especially in some sports, and knowledge relating to fitness (compare KIRK, 2010). These tensions between physical education and activation can also be related to research by Swartling Widerström (2005), Quennerstedt (2006) and Öhman (2008) about views of the body, health and 'the good student'.

In her study about views of the body in PEH, Swartling Widerström (2005) shows that while many teachers favour humanistic perspectives of the body (being a body), the PEH practice seems to foster scientific perspectives of the body (having a body). Similarly, in Quennerstedt's (2006) study, teachers often seem to favour salutogenic perspectives of health (salutogenic from salus, health), even though the $\mathrm{PEH}$ practice appears to foster pathogenic perspectives (pathogenic from pathos, suffering). This means that rather than focusing on resources for health, $\mathrm{PEH}$ practice tends to be about reducing health hazards and preventing sedentary behaviour. Further, scientific perspectives of the body and pathogenic perspectives of health match the moralistic approach to students that Öhman (2008) discovered in her study about the social construction of the PEH student. A moralistic approach means that 'a good student' is expected to be attentive to health information and respond to it, i.e., to participate in $\mathrm{PEH}$, be active and benevolent.

As yet no study has pulled these different strands together in a systematic metaanalysis. However, it can be speculated that humanistic and salutogenic perspectives are difficult to promote due to the consequences of a neoliberal governance that emphasises certainty, risk reduction and accountability. This kind of governance instead prioritises scientific and pathogenic perspectives (see, e.g. BALL, 2015; BALL; OLMEDO, 2013; EVANS; DAVIES, 2014). Clearly, fostering the humanistic and salutogenic perspectives of bodies and health stands out as a challenging task for contemporary physical education teachers.

Another prominent theme in Swedish PEH research is gender. To a great extent this research originates from the ambition formulated in the general national curriculum, which states that schools have a mission to 'counteract gender patterns'. 
This mission is attributable to equal opportunity objectives (although it is sometimes interpreted as counteracting gender difference for its own sake). Gender patterns can be seen as resulting from gender(ed) norms that prevent boys and girls from acting based on their individual, rather than gender designated aspirations and ambitions. This is why these patterns need to be addressed. Further, traditional gender norms typically assume the existence of two genders that are both 'opposite' and complementary -; an assumption that can hardly be maintained in today's highly individualised societies, as has been demonstrated by LGBTQI persons.

In a series of studies, Larsson and colleagues have explored gender(ed) norms in PEH and how these gender patterns might be counteracted (JOY; LARSSON, 2019; LARSSON; FAGRELL; REDELIUS, 2009; LARSSON; REDELIUS; FAGRELL, 2011; LARSSON; QUENNERSTEDT; ÖHMAN, 2014; REDELIUS; FAGRELL; LARSSON, 2009). These studies have revealed that $\mathrm{PEH}$ teachers do not always interpret gender patterns as problematic in the sense that they restrict students' opportunities to participate on equal terms. In fact, scientific perspectives, in this case about 'sex differences', seem to some extent to cement the practice. The studies by Joy \& Larsson (2019) and Larsson, Fagrell, Redelius (2011) indicate that stereotypical gendered behaviour is often 'under the radar' of $\mathrm{PEH}$ teachers, possibly because they regard them as 'natural' or because challenging them would require considerable effort and could be seen as 'risky business' in relation to the ambition to keep students 'busy, happy and good' (PLACEK, 1983).

However, a study by Larsson, Quennerstedt and Öhman (2014) reveals some of the strategies that teachers could use to counteract gender(ed) norms and behaviour patterns, such as leaving room for students to challenge the dominating norms and taking students' queries seriously. Allowing students to challenge the dominating norms may, for example, mean favouring student-centred explorative teaching strategies rather than teacher-centred instructive strategies. Taking students' queries seriously may include being attentive to the often implicit norms that student resistance makes explicit, for instance heteronormativity, i.e., the taken for granted assumption that all students are (or will become) heterosexual until proven otherwise (LARSSON, QUENNERSTEDT; ÖHMAN, 2014).

\subsection{TEACHING AND LEARNING MOVEMENT CAPABILITY}

Much of the last decade's research has been devoted to showing how the educational perspective of the PEH practice could be strengthened. This includes both conventional researcher-led research and teacher-led research. Researcher-led research has mainly been conducted in the form of observations, including video filming, of PEH classes (QUENNERSTEDT et al., 2014) and has shed light on the 'nitty-gritty' of the PEH practice, such as the ways in which lessons unfold and how different forms of practice can affect how students learn. For instance, Larsson and Karlefors (2015) show that most lessons take place within the framework of a 'training session' (i.e. with warm-ups, a main activity and some form of closing activity), where movement activities are mainly reproduced by the students themselves with little communication between the teachers and the students about what the latter are 
actually expected to learn. This included lessons with physical training and games, but not lessons with dance. On the contrary, dance lessons included quite a lot of deliberation between teachers and students about both the purpose and the learning objectives. Additionally, the students were invited to explore movements and to create movement sequences, rather than mimic pre-established ones. Larsson and Karlefors (2015) suggest that this way of teaching dance lessons could serve as inspiration for all PEH teaching and that such an approach could also contribute to student learning and a greater focus on the educational perspectives of $\mathrm{PEH}$.

One particular aspect of PEH that has been prominent in research is the development of movement skills, although within a $\mathrm{PEH}$ framework this is not necessarily the same as improving skills in different sports. In order to create some distinction from conventional thinking about movement skills, whether sportsinfluenced or science-influenced (i.e. sports skills, motor skills), Nyberg (2014) developed the term 'movement capability' in a series of studies, in a way that the author believed would better match the educational aspirations of PEH. Notwithstanding, Nyberg commenced her work by exploring the capabilities of 'movement experts', although the exploration did not start from the observer's point of view, but from that of the practitioner. The basic research question was: What does one know when one knows how to do $X$ ?, which was also Nyberg's point of departure when exploring the movement capabilities of expert pole vaulters and free skiers. This question displaced the focus from technique to capability. Technique is traditionally formulated based on information that is external to the practitioner (objective description), while capability integrates both objective description and subjective experience. For instance, Nyberg (2014) found that movement experts seemed to develop their ability to discern ways of moving, navigate awareness and find alternative ways of moving or solving movement problems.

Consequently, one possible way of enhancing the educational perspective of PEH could be to develop teaching methods that would allow students to discern their ways of moving, navigate their awareness, and solve movement problems in order to develop movement capability. This could involve implicit - and often quite narrow - standards of excellence (i.e. what is 'good performance') and lead to students developing movement capability regardless of their present abilities (LARSSON; NYBERG, 2016).

Teacher-led research has been conducted within the framework of a particular graduate school for PEH teachers as part of their service in schools. Several of the projects have been interventions in which a lesson sequence with a particular focus, e.g. on health education as part of PEH (GRAFFMAN-SAHLBERG; BRUN SUNDBLAD; LUNDVALL, 2014; VESTERLUND, 2018) has been planned, taught and documented. In these studies, the focus was on the qualitative aspects of learning, i.e. how the students developed more differentiated and nuanced ways of understanding and relating to the object of learning. In contrast to the often quite short lesson sequences that conventionally characterise PEH (typically two lessons with the same content), these interventions included more extensive lesson sequences (about six to eight lessons with the same content). The results indicated that prolonged 
lesson sequences facilitated learning in the sense that the students had enough time to understand what the objective of the unit was and to explore and practise what they were expected to learn. They also revealed that student learning benefitted from teachers complementing the conventional 'how do I teach $x$ ' question with the question 'what does it mean for students to know $x$ ?' Highlighting this question seems to be more appropriate in a goal-related or criterion-referenced system, where specific learning outcomes are formulated for each subject or learning area.

Taken together, research on general educational issues and subject specific issues of $\mathrm{PEH}$, whether researcher-led or teacher-led, has revealed a number of challenges for PEH teachers and teacher educators. Many of these challenges are prompted by changes in school governance, for example the transition from a governance based on content (school knowledge perspective) to one based on goals or learning outcomes (student learning perspective). For a subject like $\mathrm{PEH}$, this has also meant a greater emphasis on education or learning. Our interpretation is that these challenges typically derive from difficulties of revaluating the practices that teachers mostly take for granted. Most teachers endeavour to change the practice within the recognised framework, i.e. they try to adapt new goals to the current practice, rather than trying to change the framework, which would mean opening up for substantial change. Some teachers seem to be able to change the framework, although this is generally regarded as a highly challenging endeavour (see, e.g. GIBBS; QUENNERSTEDT; LARSSON, 2017; GRAFFMAN-SAHLBERG; BRUN SUNDBLAD; LUNDVALL, 2014; see also CASEY; LARSSON, 2018). Changing the framework is a very demanding task that requires comprehensive cooperation between many teachers, teacher educators, researchers and others involved in forming the PEH practice.

One area that is greatly influenced by the neoliberal reforms described in the introduction is that of assessment and grading. A greater emphasis should now be placed on what students actually learn and their level of knowledge in relation to stated goals. If PEH has been transformed from a subject for 'fun and recreation' to a 'subject' for learning', could in that sense be detectable in the way teachers handle the assignment to assess and grade students. Therefore, we now turn to the topic assessment and grading, as that has been a particularly prioritised issue in Swedish $\mathrm{PEH}$ research.

\section{RESEARCH ON ASSESSMENT AND GRADING IN SWEDISH PEH}

Before presenting and evaluating some of the current research on assessment and grading, we will shortly describe the function of grades in the Swedish school system. One official and important function of grades is to serve as selection instruments to the next educational level. All grades have an equal value in this respect (and add up to an average point), which means that grades in $\mathrm{PEH}$ are highstakes and just as important as grades in other subjects. In a goal-related school system, such as the Swedish one, students are graded for accountability reasons (do teachers/schools make sure that students reach the goals?), to provide information about what kind of knowledge students have (to parents and to students themselves) 
and to increase their motivation to learn (although whether or not grades have this function is a debated issue). In all cases, it is important that grading is trustworthy and that students are assessed and graded on equal grounds regardless of gender, who their teacher is and which school they attend. Assessment and grading also have informal functions. What is assessed is an indicator of what is valued in a subject. In that sense, assessment sends a powerful message about what counts as legitimate knowledge (HAY; PENNEY, 2013). A relevant questions to ask here if therefore if students are being awarded grades in line with the intentions.

In a goal- or criterion-referenced grading system, grades should be awarded on the basis of how well students meet the stated knowledge criteria or learning outcomes. The grading criteria only include the knowledge that students are expected to acquire. The PE curriculum stresses the importance of knowledge about health, how the body works and a healthy lifestyle. Students are also expected to be able to participate in games, dance, sports and other activities and to adjust their movements appropriately to a task. However, several studies of Swedish PE have shown that how students behave is just as important as the kind of knowledge and skills they have (ANNERSTEDT; LARSSON, 2010; REDELIUS; FAGRELL; LARSSON, 2009), which indicates that teachers do not always grade in accordance with the steering documents.

In a study by Wiker (2017) about student perspectives on PEH teaching, it was apparent that the students thought they needed to have a special talent in PE before they started their PE education. The students saw prior knowledge as a requirement for obtaining a high grade in PE, which according to them was not the case in other subjects. Where did they learn that prior ability was a prerequisite for a high grade? Maybe because teaching practices in a school subject are often deeply rooted in habits, traditions and customs, and teachers normally regard the content as natural and obvious. There is still a heavy focus on doing, rather than paying attention to what to learn. From this perspective, it is then quite natural for students to imagine that they need to have learned things before a PEH class.

Other studies on students' perspectives of assessment and grading show that many students are unsure about the grading criteria and how teachers assess and determine the grades (REDELIUS; HAY, 2009; 2012). However, when asking students what they thought was important in order to receive a high grade in $\mathrm{PEH}$, they came up with a number of suggestions, many of which were not in line with the official criteria. Instead, students had the impression that trying hard, doing their best, being positive, always attending class and having the right attitude were important factors for receiving a high grade in PEH. Again, the following question can be asked, how did the students get the impression that a certain attitude was important?

Öhman and Quennerstedt (2008) have shown that teachers' exhortations and encouraging cries, such as 'good, come on, work hard, keep going, you can do it', largely pervade PEH lessons. Their results demonstrated that the primary foci in the teaching of PE were physical exertion and the fostering of good character. Furthermore, the character-building elements of teachers' comments mainly seemed concerned with the development of a willingness to be physically active (ÖHMAN; 
QUENNERSTEDT; 2008). In other words, students have largely understood that the subject is about working hard, doing their best and cooperating (and doing it with a smile). The students may have assumed, in the absence of sufficient reasons to think otherwise, that the values, beliefs and expectations promoted through the daily pedagogy formed the basis on which judgements were made. From this perspective, the students would have expected consistency between what they experienced in class and the judgements of their teachers.

In another study relating to the overall question posed in the introduction (is $\mathrm{PEH}$ a subject for learning today?), the focus was on examining whether and how aims and learning goals were communicated by the teachers in $\mathrm{PEH}$. The study was based on a socio-cultural perspective and a special focus was on scrutinising how teaching practices were framed in terms of whether and how the aims and learning goals were made explicit or not to students. The results showed that many of the students taking part in the study did not understand what they were supposed to learn in PE. However, and not surprisingly, if the goals were well articulated by the teachers, the students were more likely to both understand and be aware of the learning outcomes and what to learn. The opposite was also true. If the goals and objectives were not clarified, the students found it difficult to state the learning objectives and know what they were expected to learn.

\subsection{ASSESSMENT EFFICACY - OR NOT?}

In order to evaluate the above findings, we will use the four interdependent conditions that Hay and Penney (2009) promote for assessment efficacy in PE as a starting point. The first is a primary focus on assessment for learning. Hay and Penney emphasise that even if an assessment is done for summative purposes, such as grading and reporting, it should still be done in a way that promotes student learning. The second condition, and an overarching one, is validity. Unless the proposed assessment is valid it is useless and does not serve its purpose. When determining grades, teachers need to make sure that they are reliable, reflect the requirements and are free from irrelevant factors, such as students' dispositional and behavioural characteristics. The third condition is authentic and integrated assessment. Authenticity in assessment is concerned with the relationships between learning content and the world outside the PE classroom. Teachers should try to find tasks that are meaningful and have a value beyond the instructional context. The fourth and last condition is called socially just assessment. It concerns the opportunities that all students are given to engage in the assessment, receive attention, and have the chance to demonstrate knowledge and what they have learned. In this respect it is also important that students are "let in on the secrets of teachers' grading criteria through access to understandable criteria" (HAY; PENNEY, 2009, p 399). In addition, students should be given multiple opportunities in varying contexts to demonstrate their knowledge. The key interest in proposing these conditions is to limit the negative consequences that assessment may have, such as students' reduced sense of capacity in the PE field, their disconnection with physical culture in and beyond the classroom, and the learning of undesirable ideologies such as sexism and elitism. 
From the research that has been conducted on Swedish $\mathrm{PEH}$, we can conclude that the four conditions proposed by Hay and Penney (2009) are not always met. Students are generally not able to describe what teachers base their assessment on and they are not sure about the grading criteria. In particular, the conditions of validity and socially just assessment need to be attended to. Consequently, there is not assessment efficacy and several educational challenges therefore derive from evaluating research on assessment and grading practices.

\section{CONCLUDING COMMENTS}

It should be noted that although much of the above presented research highlights educational challenges concerning, the subject remains in fact one of the most popular ones in Swedish schools (LUNDVALL; BRUN SUNDBLAD, 2016). PEH is also regarded as important by the Swedish government. Recently an additional 100 hours were allocated to the previous 500 hours for the nine-year compulsory school, thereby increasing the mandated time allocation to 600 hours. Thus, the critical approach of the research does not necessarily indicate a generally poor quality of the teaching. To some extent it reflects the challenges that emerge from the reforms and the new neoliberal agenda that have been introduced over the last 30 years, which have not been accompanied by appropriate education and in-service training for teachers. The research that was the result of first wave of $\mathrm{PEH}$ research during the first decade of the 2000s was largely research-driven and lacked systematic attempts to offer guidelines for teachers. The second wave of $\mathrm{PEH}$ research during the 2010s, that we have presented, has had a more interventionist approach, at least the teacher-led research within the graduate school for PEH teachers. Here, PEH teacher researchers have endeavoured to offer possible ways, through intervention studies, to gain knowledge about what happens in the practice when teachers try to change it. Thus, the research can offer not only critique, but also a concrete basis for further development. Taking gender as one example, illustrating in research how gender norms benefit and hinder students in different ways seems not to be enough. Through interventionist approaches, research also needs to offer guidelines and advice on how to deal with gender issues in $\mathrm{PEH}$ teaching.

The critical approach guiding PEH research is also influenced by a 'critical friend' perspective, i.e. "a trusted person who asks provocative questions, provides data to be examined through another lens, and offers critique of a person's work as a friend" (COSTA; KALLICK, 1993, p. 50). This approach has developed as an alternative to the conventional idea of researchers as experts who know better than practitioners what the practice should look like. A critical friend of $\mathrm{PEH}$ poses challenging questions to practitioners and offers new perspectives on how to approach them. However, being a critical friend, rather than someone who merely criticises practitioners, requires effort and imagination on the part of researchers if they are to offer challenging questions in a constructive and prospective way (compare CASEY; LARSSON, 2018). It is our sincere hope that the research presented here will have both an impact and contribute in a constructive way to developing the PEH practice into the 2020 s. 


\section{REFERENCES}

ANNERSTEDT, Claes. Idrottslärarna och idrottsämnet: Utveckling, mål, kompetens - ett didaktiskt perspektiv. 1991. PhD diss (Eng. PH teachers and the PE subject) - Gothenburg: University of Gothenburg, 1991.

ANNERSTEDT, Claes; LARSSON, Staffan. 'I have my own picture of what the demands are ... ': Grading in Swedish PEH: problems of validity, comparability and fairness. European Physical Education Review, v. 16, n. 2, p. 97-115, 2010. DOI: $\underline{10.1177 / 1356336 \times 10381299}$

BALL, Stephan, J. Education, governance and the tyranny of numbers. Journal of Educational Policy, v. 30, n. 3, p. 299-301, 2015. DOI: 10.1080/02680939.2015.1013271

BALL, Stephan J.; OLMEDO, Antonio. Care of the self, resistance and subjectivity under neoliberal governmentalities. Critical Studies in Education, v. 54, n. 1, p. 85-96, 2013. DOI: $\underline{10.1080 / 17508487.2013 .740678}$

CARLGREN, Ingrid; MARTON, Ference. Lärare av i morgon (Eng. Teachers of tomorrow). Stockholm: Lärarförbundets Förlag, 2000.

CASEY, Ashley; LARSSON, Håkan. "It's Groundhog Day": Foucault's Governmentality and Crisis Discourses in Physical Education. Quest, v. 70, n. 4, p. 438-455, 2018. DOI: 10.1080/00336297.2018.1451347

CONNELL, Raewyn. The neoliberal cascade and education: an essay on the market agenda and its consequences, Critical Studies in Education, v. 54, n. 2, p. 99-112, 2013. DOI: 10.1080/17508487.2013.776990

COSTA, Arthur, L; KALLICK, Bena. Through the lens of a critical friend. Educational leadership, n. 51, p. 49-51, 1993.

DAUN, Holger. Privatisation, decentralisation and governance in education in the Czech Republic, England, France, Germany and Sweden. International Review of Education, v. 50, n. 3-4, p. 325-346, 2004.

EKBERG, Jan-Eric. Mellan fysisk bildning och aktivering. 2009. PhD diss (Eng. Between physical education and activation) - Malmö: Malmö University, 2009.

EKBERG, Jan-Eric. What knowledge appears as valid in the subject of Physical Education and Health? A study of the subject on three levels in year 9 in Sweden. Physical Education and Sport Pedagogy, v. 21, n. 3, p. 249-267, 2016. DOI: 10.1080/17408989.2014.946006

EVANS, John; DAVIES, Brian. Physical Education PLC: neoliberalism, curriculum and governance. New directions for PESP research. Sport, Education and Society, v. 19, no. 7, p. 869-884, 2014. DOI: $10.1080 / 13573322.2013 .850072$

GIBBS, Beatrice; QUENNERSTEDT, Mikael; LARSSON, Håkan. Teaching dance in physical education using exergames. European Physical Education Review, v. 23, no. 2, p. 237256, 2017. DOI: $10.1177 / 1356336 \times 16645611$

GRAFFMAN-SAHLBERG, Marie; BRUN SUNDBLAD, Gunilla; LUNDVALL, Suzanne, A Possible Mission?: An Action-based Case Study of a Teaching-Learning Model in Physical Education and Health. Swedish Journal of Sport Research, n. 1, p. 28-51, 2014.

HAY, Peter; PENNEY, Dawn. Proposing conditions for assessment efficacy in physical education. European Physical Education Review, v. 15, n. 3, p, 389-405, 2009. DOI: 10.1177/1356336X09364294 
HAY, Peter; PENNEY, Dawn. Assessment in physical education: A sociocultural perspective. London: Routledge, 2013.

JOY, Phillip; LARSSON, Håkan. Unspoken: Exploring the Constitution of Masculinities in Swedish Physical Education Classes through Body Movements. Physical Education and Sport Pedagogy, v. 24, n. 5, p. 491-505, 2019. DOI: $10.1080 / 17408989.2019 .1628935$

KIRK, David. Physical Education Futures. London: Routledge, 2010.

LARSSON, Håkan; FAGRELL, Birgitta; REDELIUS, Karin. Queering physical education. Between benevolence towards girls and a tribute to masculinity. Physical Education and Sport Pedagogy, v. 14, n. 1, p. 1-17, 2009. DOI: $10.1080 / 17408980701345832$

LARSSON, Håkan; KARLEFORS, Inger. Physical education cultures in Sweden: fitness, sports, dancing ... learning? Sport, Education and Society, v. 20, n. 5, p. 573-587, 2015. DOI: $10.1080 / 13573322.2014 .979143$

LARSSON, Håkan; NYBERG, Gunn. 'It doesn't matter how they move really, as long as they move.' Physical education teachers on developing their students' movement capabilities. Physical Education and Sport Pedagogy, v. 22, n. 2, p. 137-149, 2016. DOI: $\underline{10.1080 / 17408989.2016 .1157573}$

LARSSON, Håkan; QUENNERSTEDT, Mikael; ÖHMAN, Marie. Heterotopias in Physical Education: Towards a Queer Pedagogy? Gender and Education, v. 26, n. 2, p. 135-150, 2014. DOI: $\underline{10.1080 / 09540253.2014 .888403}$

LARSSON, Håkan; REDELIUS, Karin. Mellan nytta och nöje: Bilder av ämnet idrott och hälsa (Eng. Between Pleasure and Utility), Stockholm: Swedish School of Sport and Health Sciences, 2004.

LARSSON, Håkan; REDELIUS, Karin. Swedish Physical Education Research Questioned Current situation and future directions. Physical Education and Sport Pedagogy, v. 13, n.o 4, p. 381-398, 2008. DOI: 10.1080/17408980802353354

LARSSON, Håkan; REDELIUS, Karin; FAGRELL, Birgitta. Moving (in) the heterosexual matrix. On heteronormativity in secondary school physical education. Physical Education and Sport Pedagogy, v. 16, n. 1, p. 67-81, 2011. DOI: $10.1080 / 17408989.2010 .491819$

LUNDVALL, Suzanne; BRUN SUNDBLAD, Gunilla. Polarisering av ungas idrottande (Eng. A polarisation of Youth Sport). In: De aktiva och de inaktiva. Stockholm: Centrum för idrottsforskning, 2016, p. 45-75.

NILSSON LINDSTRÖM, Margareta; BEACH, Dennis. Changes in teacher education in Sweden in the neo-liberal education age: Toward an occupation in itself or a profession for itself?, Education Inquiry, v. 6, n. 3, p. 241-258, 2015. DOI: 10.3402/edui.v6.27020

NYBERG, Gunn. Ways of knowing in ways of moving: A study of the meaning of capability to move. 2014. PhD diss.(Sport and health Sciences) _ Stockholm: Stockholm University, 2014.

ÖHMAN, Marie. Kropp och makt i rörelse (Eng. Body and Power in Motion). Örebro: Örebro University, 2007.

ÖHMAN, Marie; QUENNERSTEDT, Mikael. Feel good—be good: subject content and governing processes in physical education. Physical Education and Sport Pedagogy, v. 13, n. 4, p. 365-379, 2008. DOI: 10.1080/17408980802353339

PLACEK, Judith. "Conceptions of success in teaching: Busy, happy and good?". In:

Teaching in Physical Education. Champaign, IL: Human Kinetic, 1983. p. 46-56. 
QUENNERSTEDT, Mikael. Att lära sig hälsa (Eng. Learning Health). PhD diss. Örebro: Örebro University, 2006.

QUENNERSTEDT, Mikael; ANNERSTEDT, Claes; BARKER, Dean; KARLEFORS, Inger; LARSSON, Håkan; REDELIUS, Karin; ÖHMAN, Marie. What did they learn in school today? A method for exploring aspects of learning in physical education. European Physical Education Review, v. 20, n. 2, p. 282-302, 2014. DOI: 10.1177/1356336X14524864

REDELIUS, Karin; FAGRELL, Birgitta; LARSSON, Håkan. Symbolic capital in physical education and health. To do, to be or to know? That is the gendered question. Sport, Education and Society, v. 13, n. 4, p. 381-398, 2009. DOI: $10.1080 / 13573320902809195$

REDELIUS, Karin; HAY; Peter. Defining, acquiring and transacting cultural capital through assessment in physical education. European Physical Education Review, v. 15, n. 3, p. 275-294, 2009.

REDELIUS, Karin; HAY, Peter. Student views on criterion-referenced assessment and grading in Swedish physical education, Physical Education and Sport Pedagogy, v. 17, n. 2, p. 211-225, 2012. DOI: 10.1080/17408989.2010.548064

REDELIUS, Karin; LARSSON, Håkan. Physical Education in Sweden: an overview and some educational challenges, Sport in Society, v. 13, n. 4, p. 691-703, 2010. DOI: $\underline{10.1177 / 1356336 \times 09364719}$

REDELIUS, Karin; QUENNERSTEDT, Mikael; ÖHMAN, Marie. Communicating aims and learning goals in physical education: part of a subject for learning? Sport, Education and Society, v. 20, n. 5, p. 641-655, 2015. DOI: 10.1080/13573322.2014.987745

SKOLVERKET. Curriculum for the compulsory school, preschool class and the recreation centre 2011, Stockholm: Skolverket, 2011.

SKOLVERKET. Curriculum for the compulsory school, preschool class and the recreation centre 2011, Stockholm: Skolverket, 2020.

SWARTLING WIDERSTRÖM, Katarina. Att ha eller vara kropp? En textanalytisk studie av skolämnet idrott och hälsa (Eng. To have or to be a body?). PhD diss. Örebro: Örebro University, 2005.

VESTERLUND, Sabina. Hälsa med andra ord: Innebörden av att genomföra och värdera street dance utifrån begriplighet, hanterbarhet och meningsfullhet (Eng. Health in Other Words). Lic diss. Stockholm: The Swedish School of Sport and Health Sciences, 2018.

WIKER, Madeleine. 'Det är live liksom': Elevers perspektiv på villkor och utmaningar i idrott och hälsa (Eng. Students' perspective of PE), Karlstad: Karlstads Universitet, 2017. 